\title{
ФАКТОРЫ ПРОСТРАНСТВЕННОЙ ИЗМЕНЧИВОСТИ РЕЧНОГО СТОКА В ЦЕНТРАЛЬНОЙ ЯКУТИИ
}

\author{
(C) 2020 г. Л. С. Лебедева ${ }^{a, *}$, О. М. Макарьева ${ }^{a, b}$ \\ ${ }^{a}$ Институт мерзлотоведения им. П.И. Мельникова СО РАН, Якутск, Россия \\ ${ }^{b}$ Санкт-Петербургский государственный университет, Санкт-Петербург, Россия \\ *e-mail: lyudmilaslebedeva@gmail.com \\ Поступила в редакцию 27.08.2019 г. \\ После доработки 23.05.2020 г. \\ Принята к публикации 06.06.2020 г.
}

\begin{abstract}
На основе анализа рядов суточных расходов воды по всем действующим и закрытым в последние десятилетия гидрологическим постам на малых и средних реках Центральной Якутии установлено, что среднемноголетний слой речного стока и его коэффициент вариации изменяются в очень широких пределах. Количество осадков и величина испарения относительно стабильны в пространстве. Условия увлажнения предшествующих лет влияют на формирование речного стока текущего года. Выявлена замедленная реакция на осадки стока малых рек за год и месяц по сравнению с более крупными реками региона. Чем выше доля межаласного типа местности, для которого характерно распространение термокарстовых озер и понижений, тем ниже слой стока, выше его коэффициент вариации и меньше продолжительность стока. Чем выше доля склонового типа местности, тем выше среднемноголетний и максимальный суточный сток рек, а также дольше продолжительность стока. Оценка среднемноголетнего испарения имеет обратную связь с долей склонового типа местности. Распространение термокарстовых понижений, характерное для межаласного типа местности, обусловливает низкий сток рек за счет отсутствия разгрузки воды в реку с термокарстовых озер и их частных водосборов и повышенного испарения с водной поверхности озер. Показана ведущая роль ландшафтного фактора в формировании стока малых и средних рек Центральной Якутии.
\end{abstract}

Ключевые слова: речной сток, пространственная изменчивость, коэффициент вариации, испарение, мерзлотные ландшафты, водный баланс

DOI: $10.31857 / \mathrm{S} 258755662005009 \mathrm{X}$

\section{ВВЕДЕНИЕ}

Климатические факторы формирования стока рек играют различную роль в зависимости от свойств подстилающей поверхности на водосборе. Оценки влияния различных ландшафтов на временную и пространственную изменчивость речного стока были сделаны на масштабах от малых водосборов до крупных речных бассейнов во многих регионах России вне зоны многолетней мерзлоты [5, 6, 8, 12, 14, 19 и др.]. В криолитозоне России гидрологическая роль мерзлотных ландшафтов была описана на примере малых водосборов на гидрологических стационарах (Колымская водно-балансовая станция [16], Могот [3, 13], Суонаннаах [18], Западно-Сибирская экспедиция ГГИ [7] и реки бассейна оз. Байкал [1]), однако практически нет подобных оценок для средних и крупных речных бассейнов. Большое разнообразие ландшафтов криолитозоны России С.К. Аржакова [2] поделила на два района, существенно различающихся по условиям формирования речного стока: горный и равнинный. На примере малоизу- ченного горного района криолитозоны на Северо-Востоке России В.М. Михайлов [11] показал, что морфодинамический тип русла является одним из важных факторов формирования максимальных расходов рек.

В [17] отмечается, что даже близко расположенные равнинные реки Центральноякутской низменности характеризуются отсутствием синхронности в колебаниях стока. Именно этот район имеет наименьшие значения годового стока во всем Лено-Индигирском регионе, что объясняется как небольшим количеством осадков, так и широким распространением термокарста [17]. К.П. Воскресенский [4] отмечал, что на территории бывшего СССР Центральная Якутия была единственным регионом в зоне тайги, характеризующимся крайне низким стоком, сравнимым со стоком рек в степях и пустынях.

Авторами исследования была поставлена цель оценить роль климатических и ландшафтных факторов в пространственной изменчивости ха- 

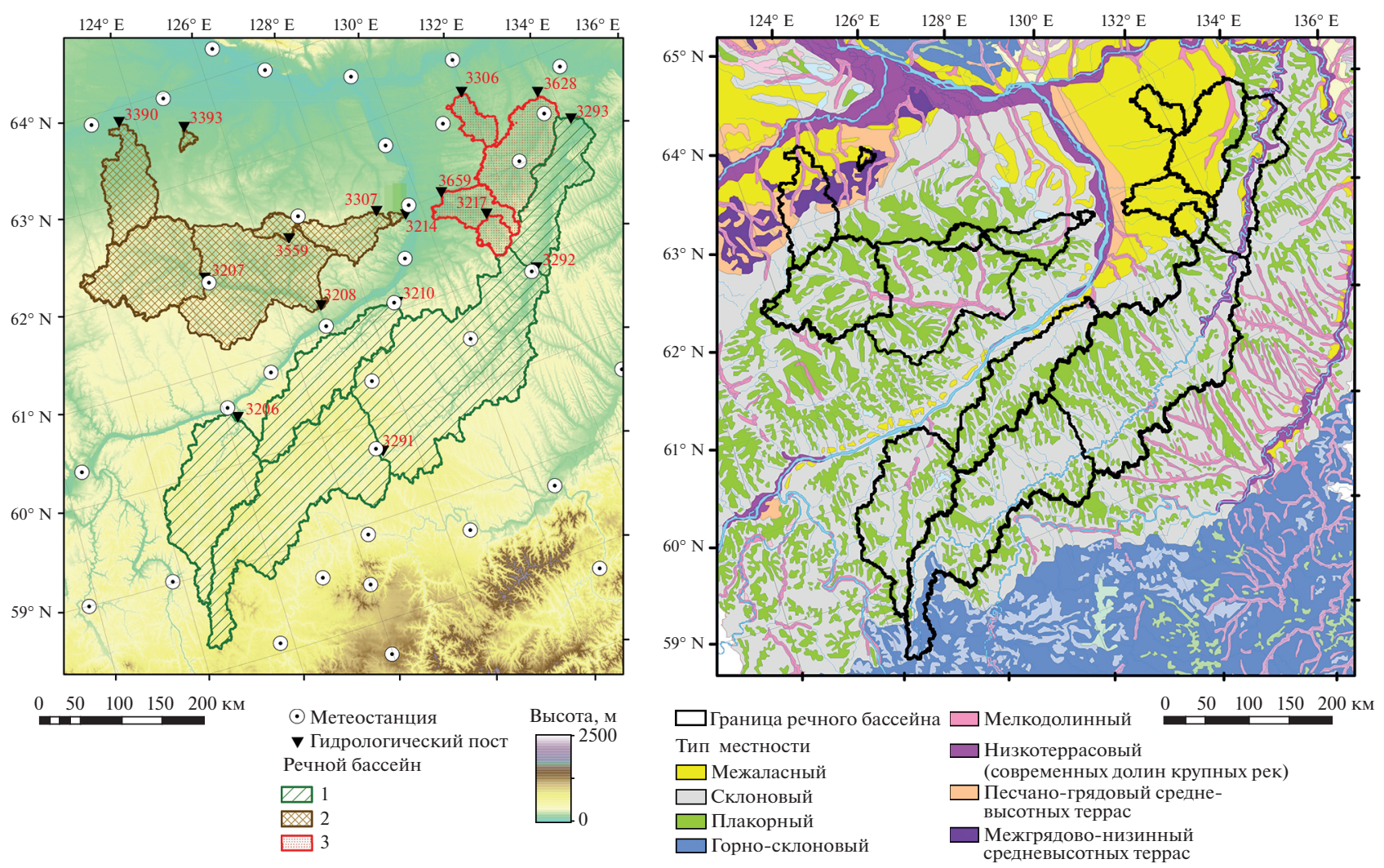

Рис. 1. Схема расположения исследуемых речных бассейнов: 1 - реки с устойчивым высоким стоком, 2 - переходная группа, 3 - реки с неустойчивым низким стоком (слева). Фрагмент мерзлотно-ландшафтной карты Якутии $1: 2500000$ [10] с границами исследуемых водосборов (справа).

рактеристик речного стока в пределах Центральной Якутии.

\section{ОБЪЕКТЫ ИССЛЕДОВАНИЯ}

Для анализа речного стока были выбраны все действующие или закрытые в последние десятилетия гидрологические посты на малых и средних реках Центральной Якутии - 16 речных бассейнов с площадями водосборов от 170 до $65400 \mathrm{Kм}^{2}$. Выбранные реки показаны на рис. 1, а их характеристики представлены в табл. 1. Коэффициенты вариации, рассчитанные для рек с десятилетним рядом наблюдений (р. Харыйа-Юрэх и р. Таатта) имеют пониженную точность.

Для оценки осадков были использованы суточные данные на 20 метеорологических станциях в пределах и в непосредственной близости от выбранных речных бассейнов (рис. 3, слева). Станции располагаются на высотах от 85 до 283 м н. у. м., а отметки местности в пределах водосборов рек Амга, Туолба и Буотама достигают 700-1200 м н. у. м. Осредненные по ближайшим метеостанциям осадки для водосборов перечисленных рек могут быть занижены из-за невозможности учета увеличения осадков с высотой местности, так как отсутствуют метеорологические станции на отметках выше 283 м н. у. м.

Исследуемый район относится к Приленскому плато и юго-восточной части Центрально-Якутской низменности в пределах Лено-Алданского и Лено-Вилюйского междуречья. Река Тангнары относится к бассейну Вилюя. Реки Шестаковка, Маатта и Синяя являются левыми притоками р. Лены различных порядков. Реки Суола, Буотама и Туолба впадают в Лену справа. Реки Амга, Таатта и Танда - левые притоки р. Алдан. Исследуемые речные бассейны Центральной Якутии располагаются в зоне средней тайги и сплошного распространения многолетней мерзлоты. Верхняя часть бассейна р. Амги и р. Туолбы находятся в зоне несплошной многолетней мерзлоты.

\section{МЕТОДЫ}

Для исследования взаимосвязи между речным стоком, осадками и ландшафтной структурой водосбора был использован корреляционный анализ. Для каждого ряда расходов были рассчитаны: 1) слои стока за каждый год, мм; 2) продолжительность стока за каждый год, сутки; 3) максимальный суточный расход $\left(\mathrm{M}^{3} / \mathrm{c}\right)$ и слой стока за 
Таблица 1. Характеристики исследуемых речных бассейнов

\begin{tabular}{|c|c|c|c|c|c|c|c|}
\hline$I$ & Река-пост & $A, \mathrm{KM}^{2}$ & $H, \mathrm{M}$ & $L$, годы: Y & $F$, мм & $\mathrm{Cv}$ & $P, \mathrm{MM}$ \\
\hline 3206 & $\begin{array}{l}\text { Туолба-пос. Алексе- } \\
\text { евка }\end{array}$ & 14400 & $131-737$ & $\begin{array}{c}\text { 58: } 1935-1937,1941-1954 . \\
1956-1985,1989-1999\end{array}$ & 148 & 0.30 & 338 \\
\hline 3207 & Синяя-гм.ст. Тонгулах & 11600 & $172-425$ & $41: 1972-1998,2001-2014$ & 54 & 0.61 & 248 \\
\hline 3208 & Синяя-г.п. Песчаное & 30400 & $118-449$ & $\begin{array}{c}28: 1956-1957,1959-1969, \\
1971-1982,1984-1986\end{array}$ & 24 & 0.90 & 266 \\
\hline 3210 & Буотома-г.п. Бролог & 12200 & $105-675$ & $77: 1936-1939,1942-2014$ & 111 & 0.38 & 300 \\
\hline 3214 & $\begin{array}{l}\text { Шестаковка-Камырда- } \\
\text { гыстах }\end{array}$ & 170 & $123-301$ & $65: 1951-2015$ & 25 & 0.87 & 237 \\
\hline 3217 & Суола-пос. Бютейдях & 1270 & $166-383$ & $36: 1960-1969,1971-1996$ & 17 & 1.35 & 248 \\
\hline 3291 & Амга-с. Буяга & 23900 & $288-1264$ & 78: $1937-2014$ & 171 & 0.30 & 388 \\
\hline 3292 & Амга-с. Амга & 56800 & $319-1264$ & 60: $1955-2014$ & 113 & 0.40 & 303 \\
\hline 3293 & Амга-с. Терют & 65400 & $81-1264$ & $\begin{array}{c}\text { 76: } 1937-1938,1940-1972, \\
1974-2014\end{array}$ & 104 & 0.38 & 286 \\
\hline 3306 & $\begin{array}{l}\text { Танда-с. Бярия } \\
\text { (Бярийе) }\end{array}$ & 2000 & $116-255$ & $\begin{array}{c}24: 1968-1976,1978-1979, \\
1981-1985,1989-1996\end{array}$ & 8 & 1.71 & 256 \\
\hline 3307 & $\begin{array}{l}\text { Кэнгкэмэ-3. Второй } \\
\text { Станок }\end{array}$ & 3550 & $201-368$ & 69: $1946-2014$ & 23 & 1.08 & 254 \\
\hline 3390 & Тангнары-с. Чай & 5760 & $101-373$ & 51: 1964-2014 & 43 & 0.64 & 280 \\
\hline 3393 & $\begin{array}{l}\text { Харыйа-Юрэх (устье)- } \\
\text { пос. Арыктах }\end{array}$ & 375 & $143-219$ & $\begin{array}{c}10: 1978,1981-1986,1989 \\
1991,1993\end{array}$ & 41 & 0.69 & 266 \\
\hline 3559 & Маатта-с. Бердигестях & 1160 & $209-360$ & 17: 1978-1981, 1984-1996 & 29 & 0.55 & 266 \\
\hline 3628 & Таатта-с. Уолба & 8290 & $143-401$ & $\begin{array}{c}10: 1985-1986,1988-1990 \\
1992-1996\end{array}$ & 1 & 1.43 & 251 \\
\hline 3659 & Суола-с. Бедеме & 3380 & $91-387$ & $\begin{array}{l}25: 1985,1989-1992,1994- \\
1998,2000-2010,2012-2014\end{array}$ & 15 & 1.20 & 248 \\
\hline
\end{tabular}

$I$ - индекс поста, $A$ - площадь водосбора, $H$ - высоты водосбора, $L$ - длина ряда данных, $Y$ - границы периодов наличия данных, $F$ - среднемноголетний слой стока, $\mathrm{Cv}-$ коэффициент вариации, $P$ - среднемноголетнее количество осадков.

каждый год, мм/сут; 4) минимальный суточный расход $\left(\mathrm{M}^{3} / \mathrm{c}\right)$ и слой стока за каждый год, мм/сут; 5) слой стока за каждый месяц, мм/мес.; 6) среднемесячные слои стока за весь период наблюдений на посту, мм/мес.; 7) среднемноголетние значения слоя стока за год (мм/год), продолжительность стока (дни), максимального и минимального суточного расхода $\left(\mathrm{M}^{3} / \mathrm{c}\right)$, слоя стока (мм/сут), коэффициент вариации годового слоя стока (б/p, Cv). При вычислении годовых величин игнорировались годы с пропусками данных. Были рассчитаны среднемноголетние, годовые и месячные значения осадков для каждого водосбора путем осреднения данных на метеорологических станциях, расположенных на водосборе и в непосредственной близости от его границ. Рассчитывались линейные коэффициенты корреляции рядов слоев речного стока за гидрологический год с рядами осадков за соответствующий год, а также суммами осадков за два, три, четыре, пять и шесть предшествующих лет. Оценивалась линейная корреляция стока за период половодья (апрель и май) с суммами осадков за зиму и предшествующие месяцы. Были рассчитаны линейные коэффициенты корреляции слоев стока за месяц с осадками за соответствующий месяц, а также суммами осадков за два и более предшествующих месяца.

Для каждого речного бассейна были рассчитаны доли типов местности. Распространение типов местности принималось согласно мерзлотноландшафтной карте Якутии масштаба 1 : 2500000 [10]. Строились линейные корреляционные зависимости между рассчитанными среднемноголетними гидрологическими характеристиками и долями типов местности, на основании чего были сделаны выводы о гидрологической роли различных типов местности.

\section{РЕЗУЛЬТАТЫ}

\section{Среднемноголетние характеристики речного стока}

Среднемноголетний слой стока рек Центральной Якутии изменяется от 1 (р. Таатта-с. Уолба, $8290 \mathrm{KM}^{2}$ ) до $171 \mathrm{мм} / г$. (р. Амга-с. Буяга, $23900 \mathrm{KM}^{2}$ ).

На графике связи среднемноголетних значений стока с площадью водосбора (рис. 2в) видно, что небольшие речные бассейны площадью до 12000 км$^{2}$ имеют низкий сток от 1 до 70 мм. Крупные водосборы с площадями более $12000 \mathrm{KM}^{2}$ характеризуется большим разбросом значений реч- 
(a)

Индекс поста

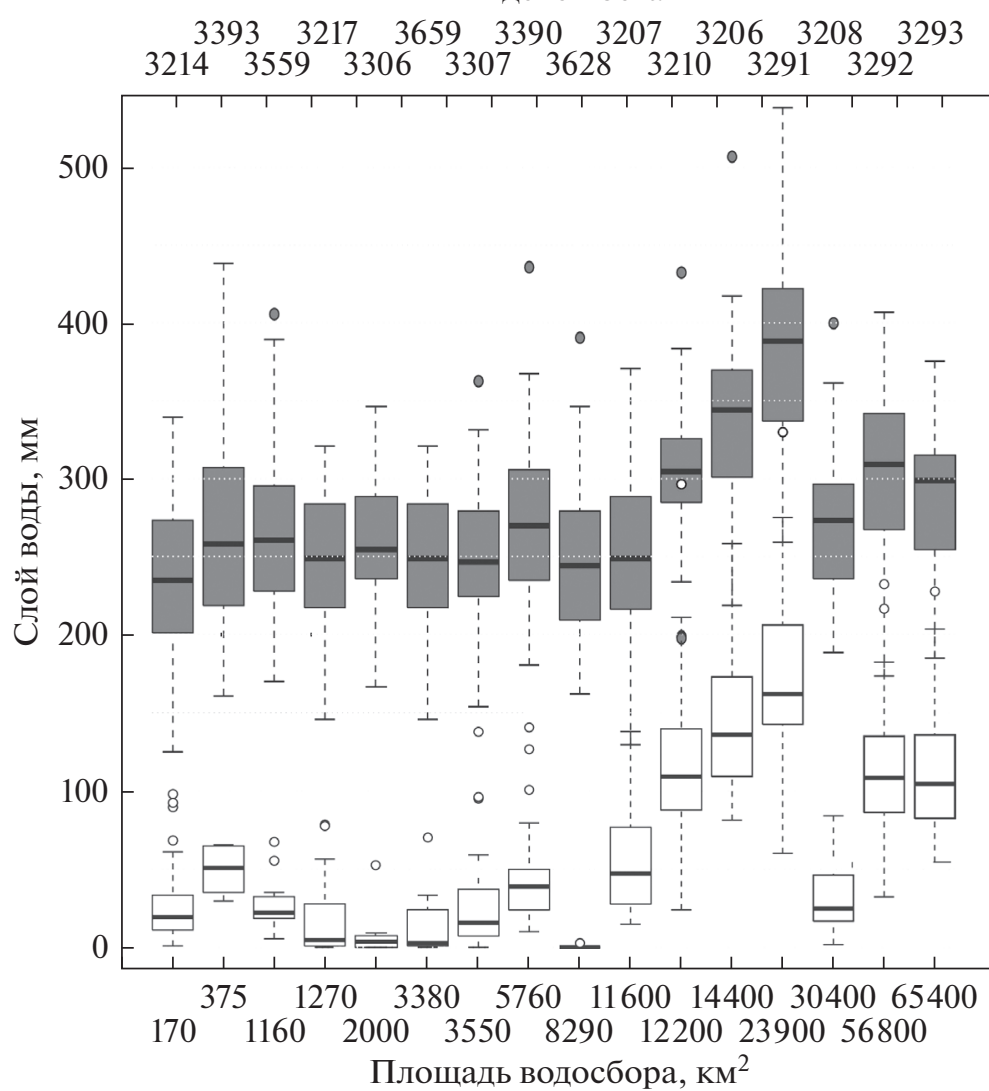

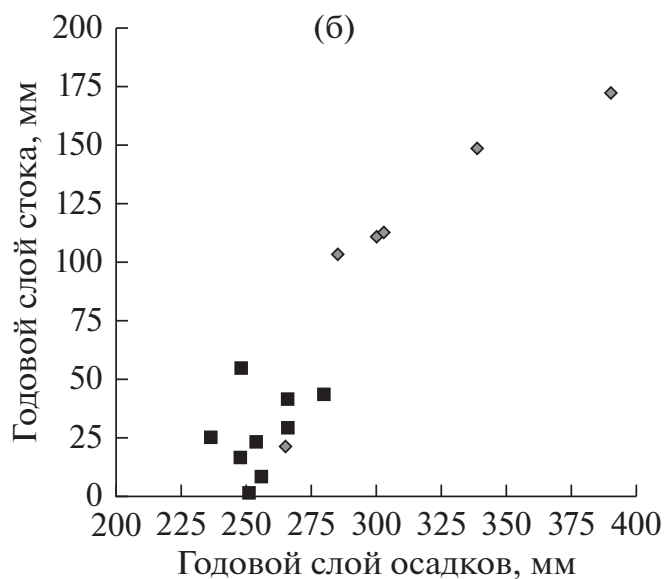

(в)

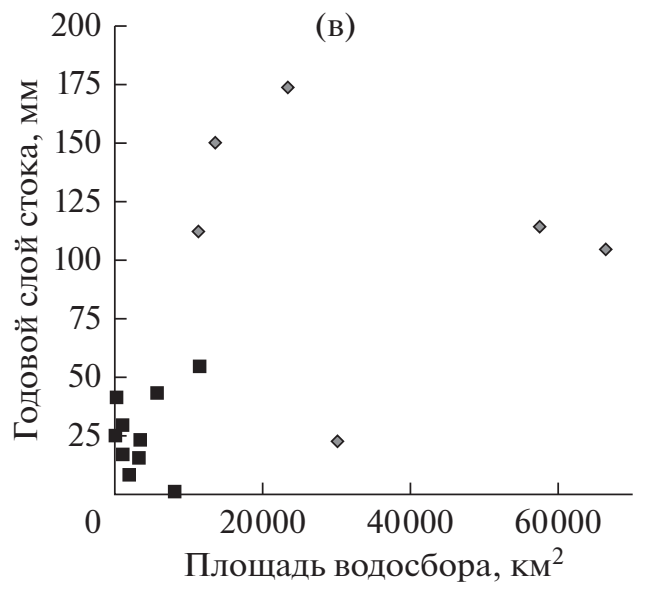

Рис. 2. а - диапазон многолетних изменений годового стока (белый цвет) и годовых сумм атмосферных осадков (серый цвет) для 16 исследуемых речных бассейнов; б - зависимость среднемноголетнего годового речного стока от годовой суммы атмосферных осадков; в - зависимость среднемноголетнего годового стока от площади водосбора. Серыми ромбами показаны водосборы с площадью более $12000 \mathrm{KM}^{2}$.

ного стока - от 24 до 171 мм. Зависимость стока от площади водосбора не прослеживается.

Для рек с длиной ряда более 20 лет были оценены значения коэффициенты автокорреляции.

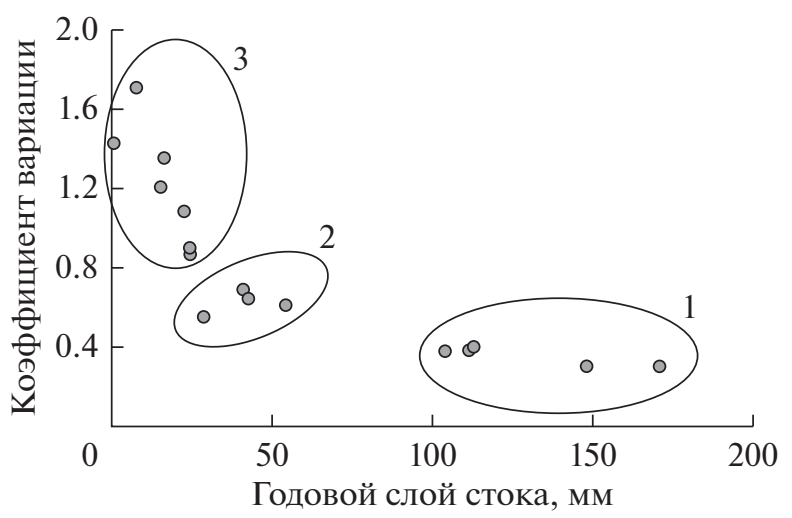

Рис. 3. Зависимость коэффициента вариации от среднемноголетнего годового слоя стока исследуемых речных бассейнов (см. рис. 1).
Относительно высокие значения (более 0.4 ) характерны для малых и средних рек - Шестаковки $\left(170 \mathrm{kм}^{2}\right)$, Кэнгкэмэ (3550 км²), Суолы $\left(3380\right.$ км$\left.^{2}\right)$ и Тангнары $\left(5760\right.$ км$\left.^{2}\right)$. На крупных реках зависимость стока за текущий год от его значения за предыдущий год не прослеживается.

На графике связи среднемноголетних значений осадков и стока (рис. 2б) выделяются точки, соответствующие водосборам с осадками менее 280 мм, стоком менее 70 мм и площадями менее 12000 км² $^{2}$ где связь осадков и стока не прослеживается. Сток рек с водосборами более $12000 \mathrm{kм}^{2}$, осадками более 280 мм составляет более 100 мм и зависит от количества осадков. Исключением является р. Синяя-г.П. Песчаное, которая имеет

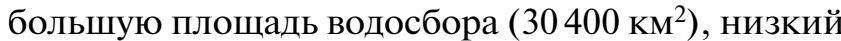
сток - 24 мм и осадки - 266 мм, это единственная из крупных рек, попадающая в облако точек с отсутствием связи между стоком и осадками.

Среднемноголетняя оценка испарения, рассчитанная как разность между осадками и стоком, варьируется в относительно узких пределах - от 182 до 250 мм/г. По результатам экспериментальных 
исследований, испарение в лесах Центральной Якутии оценивается от 140 до 260 мм/г. [15, 21-23].

Коэффициент вариации $(\mathrm{Cv})$ годового стока, характеризующий его межгодовую изменчивость, изменяется от 0.3 (р. Туолба-пос. Алексеевка, $14400 \mathrm{kм}^{2}$ и р. Амга-с. Буяга, $23900 \mathrm{Kм}^{2}$ ) до 1.71 (Танда-с. Бярия (Бярийе), 2000 км²).

Значения среднемноголетнего годового стока и коэффициента вариации годового стока показаны на рис. 3. По соотношению величин годового стока и его временной изменчивости исследуемые реки можно условно разделить на три группы (см. рис. 3 и рис. 1 слева):

1. Реки с устойчивым высоким стоком: сток более 100 мм/г., Cv менее 0.4, коэффициент стока более 0.35 . В эту группу входят крупные реки региона: Амга, Буотама и Туолба с площадями водосборов более $12000 \mathrm{Kм}^{2}$ и количеством осадков от 286 до 388 мм/год. Исключение составляет р. Синяя-г.п. Песчаное с площадью бассейна 30400 км²$^{2}$, которая характеризуется пониженным стоком (24 мм), низким коэффициентом стока $(0.09)$ и его высокой межгодовой изменчивостью (Cv 0.9), что связано, по-видимому, с низким количеством осадков (266 мм). Реки этой группы не перемерзают и не пересыхают, сток воды наблюдается постоянно. За весь период наблюдений только на р. Буотоме в 2001 г. наблюдалась полное пересыхание на 64 дня. Оценка испарения составляет от 182 до 216 мм/г.

2. Переходная группа: сток рек от 20 до 100 мм/г., Cv от 0.4 до 1.1, коэффициент стока от 0.09 до 0.22 . В эту группу вошли реки Шестаковка, Харыйа-Юрэх, Маатта, Тангнары, Кэнгкэмэ и Синяя с большим разбросом площадей от 80 до 30400 км²$^{2}$. Реки этой группы перемерзают и могут пересыхать в течение некоторого периода, однако сток воды регистрируется ежегодно. Среднемноголетняя продолжительность стока составляет от 96 до 234 дней, в маловодные годы - от 37 до 184 дней. Среднемноголетние осадки меняются в пределах 237-280 мм/г., а испарение - 194-242 мм/г.

3. Реки с неустойчивым низким стоком: сток менее 24 мм/г., Сv более 1.1, коэффициент стока менее 0.09 . В эту группу входят реки Суола, Танда и Таатта с площадями водосборов от 1270 до 8290 км² $^{2}$ Реки этой группы в течение отдельных лет полностью перемерзают, пересыхают и не дают стока в течение всего года. Среднемноголетняя продолжительность стока составляет от 89 до 157 дня. Осадки варьируются в узких пределах от 248 до 256 мм/г. Оценка испарения изменяется от 230 до $240 \mathrm{MM} / \Gamma$.

Считается [2], что сток рек зимой, в том числе промерзание рек до дна зависит от площади водосбора, поскольку она является косвенной характеристикой подземного питания. Все исследуе- мые реки с площадями водосбора менее 12000 км$^{2}$ ежегодно перемерзают. Реки с площадями водосборов более $12000 \mathrm{kм}^{2}$ текут постоянно, за исключением р. Синяя с площадью бассейна 30400 км² $^{2}$

\section{Реакция речного стока на осадки за различные временные периоды}

Годовой сток всех рассматриваемых рек имеет максимальный коэффициент корреляции с суммой осадков за текущий и один или несколько предшествующих лет (табл. 2), т.е. условия увлажнения предшествующих лет в значительной степени влияют на формирование стока текущего года. Крупные речные бассейны площадью более 20000 км $^{2}$ имеют максимальную корреляцию с суммой осадков за два года, а небольшие водосборы площадью менее $3000 \mathrm{KM}^{2}-$ с суммой осадков за 3 года и более. Это говорит о том, что малые реки имеют замедленную реакцию годового стока на осадки по сравнению с более крупными реками региона.

Низкими коэффициентами корреляции $(<0.6)$ годового стока с осадками характеризуются рр. Синяя, Туолба, Таатта, Танда и Суола в верхнем течении. Высокий коэффициент корреляции $(>0.69)$ - у рр. Тангнары, Амга, Буотома, Кэнгкэмэ, Матта, Суола в нижнем течении и Шестаковка.

Сток за период половодья (апрель и май) на многих крупных реках - Буотама, Туолба, Амга в верхнем течении и на р. Маатте, зависит от зимних осадков, то есть от суммы осадков за 8 предшествующих месяцев (октябрь-май). На рр. Шестаковка, Харыйа-Юрэх, Суола, Кэнгкэмэи и Синяя в верхнем течении сток половодья определяется как зимними осадками, так и условиями увлажнения осенью и зависит от суммы осадков за 9-10 предшествующих месяцев (август-май или сентябрь-май). На р. Синей в нижнем течении, Тангнары и Таатта сток половодья связан с осадками всего предшествующего теплого сезона и зависит от их суммы за 11-12 мес. до половодья (июнь-май или июль-май).

Сток за отдельные летние месяцы также показывает зависимость не от осадков в рассматриваемый месяц, а от суммы осадков за 2-3 мес. Сток pp. Суолы, Кэнгкэмэ, Туолбы и Синей за некоторые летние месяцы зависит от суммы осадков за лето и предшествующую зиму, а для р. Тангнары от суммы осадков за 10-12 мес.

Предположительно, на многих исследуемых бассейнах существуют механизмы задержания стока, которые приводят к замедленной гидрологической реакции на осадки. Эта задержка не зависит от площади бассейна и определяется условиями на водосборе. Типичное время реакции на летние осадки рек Буотома, Амга, Синей в верх- 

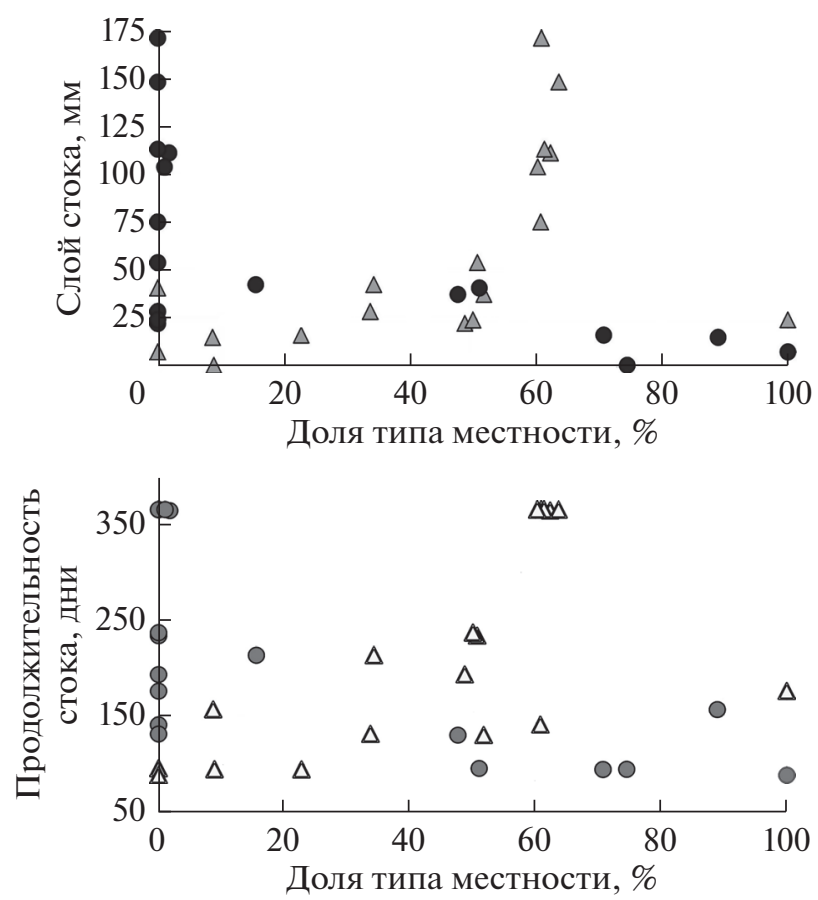

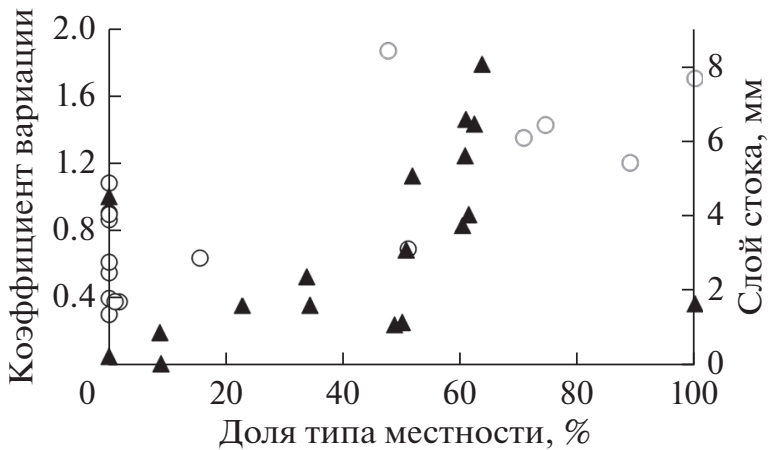

Зависимости:

Среднемноголетнего слоя стока от доли склонового

$\triangle$ типа местности

Среднемноголетнего слоя стока от доли межаласного типа местности

Максимального суточного слоя стока от доли склонового

- типа местности

Коэффициента вариации стока от доли

межаласного типа местности

Продолжительности слоя стока от доли склонового

$\Delta$ типа местности

Продолжительности слоя стока от доли межаласного

типа местности

Рис. 4. Зависимости среднемноголетнего, максимального суточного слоя стока, коэффициента вариации и продолжительности стока от доли склонового (треугольники) и межаласного (круги) типа местности.

нем течении, Шестаковка и Харыйа-Юрэх составляет от 1 до 2 мес., т.е. сток рек летнего сезона определяется, в основном, осадками, которые выпали в этом же сезоне на протяжении последних двух месяцев. На остальных реках зимние осадки и/или условия увлажнения прошлого года значительно влияют на летний сток. Во многих случаях сток более крупных рек (Амга, Буотома, Туолба) является более чувствительным к метеорологическому воздействию, чем сток малых рек.

\section{Связь характеристик речного стока с типами местности}

Согласно Мерзлотно-ландшафтной карте [10], основными типами местности на исследуемых водосборах являются склоновый, плакорный и межаласный (схема типов местности показана на рис. 1 справа). Рассчитанные доли типов местности для каждого речного бассейна показаны в табл. 3. Описания типов местностей приведены в табл. 4.

Были построены и проанализированы зависимости среднемноголетнего значения и коэффициента вариации годового стока, продолжительности стока и максимального суточного слоя стока от доли наиболее распространенных межаласного, плакорного и склонового типов местностей (см. рис. 1). Анализ показал, что чем выше доля межаласного типа местности в речном бассейне, тем ниже и неустойчивее сток (коэф- фициент вариации выше, продолжительность меньше). Река Танда (2000 км², индекс 3306), полностью покрытая межаласным типом местности, характеризуется самым коротким периодом стока (89 дней) и низкой водностью $(8 \mathrm{Mм} /$ г.). Только р. Таатта (8290 км², индекс 3628$)$ имеет сток ниже, чем на р. Танда, который равен 1 мм/г. $75 \%$ бассейна р. Таатты относится к межаласному типу местности.

Чем выше доля склонового типа местности в речном бассейне, тем выше среднемноголетний и максимальный суточный сток рек, а также дольше период стока. Речные бассейны с долей склонового типа более $60 \%$ характеризуются среднемноголетним стоком выше 75 мм/г. и максимальным суточным слоем стока более 3 мм/сут. Среднемноголетнее испарение имеет обратную связь с долей склонового типа местности, изменяясь от 225-248 мм/г. при отсутствии склонового типа на водосборе до 182-189 мм/г. при его доле 60$64 \%$. Исключением является р. Шестаковка, бассейн которой полностью покрыт склоновым типом местности, однако имеет невысокий среднемноголетний $(25 \mathrm{mм} /$ г.) и максимальный суточный (1.64 мм/сут.) сток и значительное испарение (212 мм/г.). Это может быть связано с несоответствием масштаба используемой карты типов местности $(1: 2500000)$ и площадью бассейна р. Шестаковки, равной 170 км²$^{2}$, а также с локальными условиями на водосборе, такими как 
Таблица 2. Максимальные значения коэффициента корреляции $(R)$ речного стока (за год, половодье, июль, август и сентябрь) с осадками и соответствующие им периоды суммирования осадков $(L)$. Реки расположены в порядке возрастания площади водосбора

\begin{tabular}{|c|c|c|c|c|c|c|}
\hline \multirow{3}{*}{ Индекс } & \multirow{3}{*}{ Река-пост } & \multicolumn{5}{|c|}{ Сток за } \\
\hline & & \multirow{2}{*}{$\begin{array}{c}\text { год } \\
L, \text { годы } / R\end{array}$} & половодье & июль & август & сентябрь \\
\hline & & & \multicolumn{4}{|c|}{$L$, месяцы $/ R$} \\
\hline 3214 & Шестаковка-гп. Камырдагыстах & $3 / 0.73$ & $10 / 0.77$ & $2 / 0.69$ & $1 / 0.72$ & $2 / 0.67$ \\
\hline 3393 & Харыйа-Юрэх (Устье)-пос. Арыктах & $-1-$ & $10 / 0.67$ & $1 / 0.24$ & $1 / 0.85$ & $3 / 0.82$ \\
\hline 3559 & Маатта-с. Бердигестях & $3 / 0.70$ & $8 / 0.68$ & $3 / 0.52$ & $2 / 0.70$ & $4 / 0.68$ \\
\hline 3217 & Суола-пос. Бютейдях & $3 / 0.59$ & $9 / 0.79$ & $2 / 0.28$ & $11 / 0.39$ & $2 / 0.33$ \\
\hline 3306 & Танда-с. Бярия (Бярийе) & $6 / 0.69$ & - & $2 / 0.36$ & $2 / 0.56$ & $3 / 0.52$ \\
\hline 3659 & Суола-с. Бедеме & $2 / 0.74$ & $10 / 0.71$ & $10 / 0.65$ & $2 / 0.65$ & $2 / 0.70$ \\
\hline 3307 & Кэнгкэмэ-з. Второй Станок & $3 / 0.75$ & $10 / 0.63$ & $2 / 0.42$ & $12 / 0.68$ & $2 / 0.76$ \\
\hline 3390 & Тангнары-с. Чай & $2 / 0.83$ & $11 / 0.71$ & $10 / 0.51$ & $12 / 0.72$ & $5 / 0.61$ \\
\hline 3628 & Таатта-с. Уолба & $4 / 0.39$ & $12 / 0.55$ & $2 / 0.72$ & $3 / 0.64$ & $4 / 0.54$ \\
\hline 3207 & Синяя-гм.ст. Тонгулах & $2 / 0.43$ & $9 / 0.51$ & $2 / 0.35$ & $1 / 0.49$ & $2 / 0.75$ \\
\hline 3210 & Буотома-гп. Бролог & $2 / 0.77$ & $8 / 0.75$ & $2 / 0.65$ & $1 / 0.72$ & $2 / 0.80$ \\
\hline 3206 & Туолба-пос. Алексеевка & $3 / 0.57$ & $8 / 0.64$ & $1 / 0.63$ & $11 / 0.57$ & $2 / 0.72$ \\
\hline 3291 & Амга-с. Буяга & $2 / 0.77$ & $8 / 0.77$ & $2 / 0.62$ & $2 / 0.74$ & $2 / 0.78$ \\
\hline 3208 & Синяя-гп. Песчаное & $2 / 0.35$ & $11 / 0.47$ & $2 / 0.44$ & $12 / 0.67$ & $3 / 0.67$ \\
\hline 3292 & Амга-с. Амга & $2 / 0.81$ & $8 / 0.80$ & $2 / 0.56$ & $2 / 0.78$ & $2 / 0.78$ \\
\hline 3293 & Амга-с. Терют & $2 / 0.78$ & $10 / 0.81$ & $2 / 0.59$ & $2 / 0.70$ & $2 / 0.77$ \\
\hline
\end{tabular}

Таблица 3. Доля типов местности для каждого исследуемого речного бассейна (в \%)*

\begin{tabular}{l|r|r|r|r|r|r|r|r|r|r|r|r|r|r|r|r}
\hline \multicolumn{1}{c}{ Тип местности } & 3206 & 3207 & 3208 & 3210 & 3214 & 3217 & 3291 & 3292 & 3293 & 3306 & 3307 & 3390 & 3393 & 3559 & 3628 & 3659 \\
\hline Мелкодолинный & 2 & 2 & 6 & 0 & 0 & 0 & 0 & 1 & 1 & 0 & 7 & 7 & 0 & 3 & 9 & 0 \\
Песчано-грядовый сред- & 0 & 0 & 0 & 0 & 0 & 0 & 0 & 0 & 0 & 0 & 0 & 16 & 0 & 0 & 0 & 0 \\
невысотных террас & & & & & & & & & & & & & & & & \\
Межгрядово-низинный & 0 & 0 & 0 & 0 & 0 & 0 & 0 & 0 & 0 & 0 & 0 & 17 & 49 & 0 & 0 & 0 \\
средневысотных террас & & & & & & & & & & & & & & & & \\
Межаласный & 0 & 0 & 0 & 2 & 0 & 71 & 0 & 0 & 1 & 100 & 0 & 16 & 51 & 0 & 75 & 89 \\
Плакорный & 34 & 47 & 44 & 36 & 0 & 6 & 28 & 31 & 30 & 0 & 44 & 9 & 0 & 64 & 7 & 2 \\
Склоновый & 64 & 51 & 50 & 62 & 100 & 23 & 61 & 61 & 60 & 0 & 49 & 34 & 0 & 34 & 9 & 9 \\
Горно-склоновый & 0 & 0 & 0 & 0 & 0 & 0 & 6 & 2 & 2 & 0 & 0 & 0 & 0 & 0 & 0 & 0 \\
Другие & 1 & 0 & 0 & 0 & 0 & 0 & 5 & 4 & 6 & 0 & 0 & 1 & 0 & 0 & 0 & 0 \\
\hline
\end{tabular}

* Индексы постов указаны в табл. 1.

существование надмерзлотных водоносных таликов [9].

Не выявлено связи гидрологических характеристик с долей плакорного типа местности в ландшафтной структуре речного бассейна.

Характерным для межаласного типа местности является широкое распространение полигональ- но-жильных льдов и покровных суглинков с высокими значениями объемной льдистости. Глубина протаивания, как правило, не превышает 1.3 м. Повсеместно развит термокарстовый процесс, который обуславливает большое количество термокарстовых озер. Так, в бассейне р. Таатты расположено около 2300 озер, в бассейне 
Таблица 4. Характеристика распространенных типов местности (по мерзлотно-ландшафтной карте Якутии [10])

\begin{tabular}{|c|c|c|c|}
\hline $\begin{array}{c}\text { Тип } \\
\text { местности }\end{array}$ & $\begin{array}{c}\text { Преобладающие криогенные текстуры и } \\
\text { залежеобразующие льды }\end{array}$ & $\begin{array}{c}\text { Объемная льдистость, \%, } \\
\text { в скобках с учетом } \\
\text { полигонально-жильного } \\
\text { льда (ПЖЛ) }\end{array}$ & $\begin{array}{c}\text { Основные криогенные } \\
\text { процессы }\end{array}$ \\
\hline $\begin{array}{l}\text { Межалас- } \\
\text { ный }\end{array}$ & $\begin{array}{l}\text { Слоистые, линзовидные, сетчатые (торф, } \\
\text { суглинок, супесь), массивные (песок), } \\
\text { системы мощных ПЖЛ }\end{array}$ & $\begin{array}{l}\text { Суглинок: 35-65 (с ПЖЛ: } \\
\text { 45-85), песок: 30-45 } \\
\text { (с ПЖЛ: 40-70) }\end{array}$ & Термокарст \\
\hline Плакорный & $\begin{array}{l}\text { Слоистые, линзовидные (суглинок, супесь), } \\
\text { массивные (песок), корковые (грубообло- } \\
\text { мочный с заполнителем), трещинные } \\
\text { (коренные) }\end{array}$ & $\begin{array}{l}\text { Супесь: } 35-55, \text { песок: } \\
\text { 30-50, Грубообломочный } \\
\text { с заполнителем: 25-45 }\end{array}$ & $\begin{array}{l}\text { Морозобойное растрески- } \\
\text { вание }\end{array}$ \\
\hline Склоновый & $\begin{array}{l}\text { Слоистые, линзовидные (суглинок, супесь), } \\
\text { массивные (песок), корковые, базальные, } \\
\text { гольцовый лед (грубообломочный с запол- } \\
\text { нителем), трещинные (коренные) }\end{array}$ & $\begin{array}{l}\text { Супесь: } 30-65, \text { песок: } \\
\text { 30-50, Грубообломочный } \\
\text { с заполнителем: } 30-50\end{array}$ & $\begin{array}{l}\text { Криогенный крип, соли- } \\
\text { флюкция, морозобойное } \\
\text { растрескивание, курумы }\end{array}$ \\
\hline
\end{tabular}

р. Суолы - около 1600 термокарстовых озер. Кроме межаласного типа местности, термокарстовый процесс характерен для межгрядово-низинного и мелкодолинного типов. Доля типов местности, для которых характерен термокарст, хорошо согласуется с разделением речных бассейнов по величине и коэффициенту вариации стока на три группы, описанные выше. Реки первой группы с устойчивым высоким стоком имеют не более $4 \%$ площади водосборов, покрытой “термокарстовыми" типами местности. Реки третьей группы с неустойчивым низким стоком характеризуются долей “термокарстовых” типов от 48 до 100\%. Переходный тип имеет разнообразную ландшафтную структуру с долями “термокарстовых" типов от 0 до $100 \%$.

Возможными причинами низкого и неустойчивого стока рек третьей группы могут являться:

- отсутствие разгрузки воды с термокарстовых озер и их водосборов в реку из-за отсутствия уклона, то есть существование значительных бессточных областей на водосборе [21];

- высокое испарение со снега весной и с водной поверхности озер летом;

- поглощение части стока подозерными таликами и фильтрация в меж- и подмерзлотные водоносные горизонты, которые не дренируются рекой в пределах водосборных бассейнов.

\section{ВЫВОДЫ}

Выявлена высокая пространственная изменчивость стока малых и средних рек Центральной Якутии и ее неоднозначная связь с количеством осадков. Среднемноголетние значения речного стока варьируют от 1 до 171 мм/г., осадков - от 237 до 388 мм/г. Сток рек с водосборами площадью более $12000 \mathrm{kM}^{2}$, осадками более 280 мм составляет более $100 \mathrm{Mм} / г$. и зависит от количества осадков. Сток малых и засушливых рек не показывает зависимости от осадков. Оценка испарения на 16 рассматриваемых речных бассейнах изменяется от 182 до 250 мм и имеет обратную связь с долей склонового типа местности. Коэффициент вариации $(\mathrm{Cv})$ годового стока изменяется от 0.3 до 1.71.

Для всех рассматриваемых рек характерна замедленная реакция стока воды на атмосферные осадки. Годовой речной сток наиболее тесно связан с суммой атмосферных осадков за текущий и один или несколько предшествующих лет. Рассмотренные в статье малые реки имеют замедленную реакцию на осадки по сравнению с более крупными реками региона.

По соотношению величин среднемноголетнего стока и коэффициента его межгодовой изменчивости реки могут быть разделены на три группы: реки с устойчивым высоким стоком, водосборы которых преимушественно заняты склоновым типом местности, переходная группа и реки с неустойчивым низким стоком, в бассейнах которых широко распространены термокарстовые озера и понижения.

\section{ФИНАНСИРОВАНИЕ}

Исследование поддержано грантом РНФ № 19-7700055 .

\section{FUNDING}

The research was financially supported by the Russian Science Foundation, project no. 19-77-00055. 


\section{СПИСОК ЛИТЕРАТУРЫ}

1. Антипов А.Н. Ландшафтно-гидрологическая организация территории в условиях Сибири: Автореф. дис. ... Д-ра геогр. наук. М.: Институт географии PAH, 2003. 54 c.

2. Аржакова С.К. Зимний сток рек криолитозоны России. СПб.: РГГМУ, 2001. 209 с.

3. Василенко Н.Г. Гидрология рек зоны БАМ: Экспедиционные исследования. СПб.: Нестор-История, 2013. 672 c.

4. Воскресенский К.П. Норма и изменчивость годового стока рек Советского Союза. Л.: Гидрометеоиздат, 1962. $552 \mathrm{c}$.

5. Гагаринова O.B. Ландшафтно-гидрологическое районирование Прибайкалья: Автореф. дис. ... канд. геогр. наук. Иркутск: Ин-т географии СО РАН, 2001. $26 \mathrm{c.}$

6. Гидрологическая роль лесных геосистем. Иркутск: Ин-т географии СО АН, 1989. 167 с.

7. Гидрология заболоченных территорий зоны многолетней мерзлоты Западной Сибири. СПб.: ВВМ, $2009.536 \mathrm{c}$

8. Крестовский О.И. Влияние вырубок и восстановления лесов на водность рек. Л.: Гидрометеоиздат, 1986. $118 \mathrm{c}$.

9. Лебедева Л.С., Бажин К.И., Христофоров И.И., Абрамов А.А., Павлова Н.А., Ефремов В.С., Огонеров В.В., Тарбеева А.М., Федоров М.П., Нестерова Н.В., Макарьева O.M. Надмерзлотные субаэральные талики в бассейне реки Шестаковка (Центральная Якутия) // Криосфера Земли. 2019. № 1. С. 40-50.

10. Мерзлотно-ландшафтная карта Якутской АССР. Масштаб 1 : 2500000 / Гл. ред. П.И. Мельников. М.: ГУГК, 1991. 2 л.

11. Михайлов В.М. Вариации и оценки средних максимальных расходов воды в реках Северо-Востока России // Вестн. СВНЦДВОРАН. 2014. № 2. С. 21-26.

12. Молчанов A.A. Гидрологическая роль леса. М.: АН СCCP, 1960. $487 \mathrm{c}$.

13. Нестерова Н.В., Макарьева О.М., Виноградова Т.А., Лебедева Л.С. Моделирование процессов формирования стока зоны БАМ на основе данных поли- гона Могот // Водное хозяйство России. 2018. № 1. C. $18-36$

14. Онучин А.А. Причины концептуальных противоречий в оценке гидрологической роли бореальных лесов // Сибирский лесной журн. 2015. № 2. С. 41-54.

15. Поздняков Л.К. Мерзлотное лесоведение. Новосибирск: Наука, 1986. 192 с.

16. Пугачев А.А. Почвенно-растительный покров территории Колымской воднобалансовой станции / Факторы формирования общего стока горных рек в Субарктике. Магадан: СВКНИИ ДВО РАН, 2002. C. $141-166$.

17. Ресурсы поверхностных вод СССР. Т. 17. ЛеноИндигирский район. Гидрометеоиздат, 1967. 649 с.

18. Тепловодообмен мерзлотных ландшафтов Восточной Сибири и его факторы. РАН / Ред. А.Г. Георгиади, А.Н. Золотокрылин, Р.В. Десяткин и др. М.-Тверь: Триада, 2007. 576 с.

19. Ясинский С.В. Водный баланс природных зон бассейна р. Волги в разные по водности фазы многолетнего периода // Изв. РАН. Сер. геогр. 2013. № 6. C. $86-101$.

20. Dolman A.J., Maximov T.C., Moors E.J., Maximov A.P., Elbers J.A., Kononov A.V., Waterloo M.J., van der Molen $M . K$. Net ecosystem exchange of carbon dioxide and water of far eastern Siberian Larch (Larixcajanderii) on permafrost // Biogeosciences. 2004. № 1 . P. 133-146.

21. Fedorov A.N., Gavriliev P.P., Konstantinov P.Y., Hiyama T., Iijima $Y$., Iwahana $G$. Estimating the water balance of a thermokarst lake in the middle of the Lena River basin, eastern Siberia // Ecohydrology. 2014. № 7. P. $188-196$. https://doi.org/10.1002/eco.1378

22. Hamada S., Ohta T., Hiyama T., Kuwada T., Takahashi A., Maximov T.C. Hydrometeorological behaviour of pine and larch forests in eastern Siberia // Hydrol. Process. 2004. № 18. P. 23-29.

23. Ohta T., Hiyama T., Tanaka H., Kuwada T., Maximov T.C., Ohata T., Fukushima Y. Seasonal variation in the energy and water exchanges above and below a larch forest in eastern Siberia // Hydrol. Process. 2001. № 15. P. 1459-1476.

\title{
Factors of Spatial Variability of River Runoff in Central Yakutia
}

\author{
L. S. Lebedeva ${ }^{1, *}$ and O. M. Makarieva ${ }^{1,2}$ \\ ${ }^{1}$ Melnikov Permafrost Institute of the Siberian Branch of the Russian Academy of Sciences, Yakutsk, Russia \\ ${ }^{2}$ St. Petersburg State University, St. Petersburg, Russia \\ *e-mail: lyudmilaslebedeva@gmail.com
}

Based on the analysis of the daily discharges for all active and recently closed hydrological posts at the small and medium-sized rivers of Central Yakutia, it was found that the mean annual runoff and its variation coefficient significantly vary although precipitation and evaporation values are relatively stable in space. Precipitation of previous years largely influences the river runoff formation of the current year. Small-sized rivers have a delayed runoff response to rainfall compared with the larger rivers of the region at the yearly and monthly time scale. The higher the proportion of alas-type type, that has many thermokarst lakes and depressions, the lower and less stable runoff (the variation coefficient is higher, the runoff duration is shorter). The higher the proportion of slope-type terrain, the higher the mean annual and maximum daily river runoff, as well as the longer runoff duration. The mean annual evaporation correlate with the share of the slope-type terrain. Many thermokarst depressions, that are typical for the alas-type terrain, cause a low flow presumably 
due to the absence of water discharge of thermokarst lakes and their local catchments into the river and increased evaporation from the lake surface. It was shown that the landscape factor has leading role in the runoff formation of the small and medium-sized rivers in Central Yakutia.

Keywords: river runoff, spatial heterogeneity, variation coefficient, evaporation, permafrost landscapes, water balance

\section{REFERENCES}

1. Antipov A.N. Landscape-hydrological organization of territory in conditions of Siberia. Extended Abstract of Doct. Sci. (Geogr.) Dissertation. Moscow: Inst. Geogr. Russ. Acad. Sci., 2003. 54 p.

2. Arzhakova S.K. Zimnii stok rek kriolitozony Rossii [Winter Flow of Rivers of Permafrost Zone of Russia]. St. Petersburg.: RGGMU, 2001. 209 p.

3. Vasilenko N.G. Gidrologiya rek zony BAM: Ekspeditsionnye issledovaniya [Hydrology of Rivers at the Zone of Baikal-Amur Mainline: Expedition Studies]. St. Petersburg: Nestor-Istoriya Publ., 2013. 672 p.

4. Voskresenskii K.P. Norma i izmenchivost'godovogo stoka rek Sovetskogo Soyuza [Norm and Variability of Annual Streamflow of Rivers of the Soviet Union]. Leningrad: Gidrometeoizdat Publ., 1962. 552 p.

5. Gagarinova O.V. Landscape-hydrological zoning of Baikal region. Extended Abstract of Cand. Sci. (Geogr.) Dissertation. Irkutsk: Inst. Geogr. SB RAS, 2001. 26 p.

6. Gidrologicheskaya rol' lesnykh geosistem [Hydrological Role of Forest Geosystem]. Irkutsk: Inst. Geogr. Sibir. Otd. Akad. Nauk, 1989. 167 p.

7. Gidrologiya zabolochennykh territorii zony mnogoletnei merzloty Zapadnoi Sibiri [Hydrology of Wetlands of Permafrost Zone of Western Siberia]. St. Petersburg: VMM Publ., 2009. 536 p.

8. Krestovskii O.I. Vlyanie vyrubok $i$ vosstanovleniya lesov na vodnost' rek [Influence of Clear-Cutsand Renewal of Forests on Streamflow Rate]. Leningrad: Gidrometeoizdat Publ., 1986. 118 p.

9. Lebedeva L.S., Bazhin K.I., Khristoforov I.I., Abramov A.A., Pavlova N.A., Efremov V.S., Ogonerov V.V., Tarbeeva A.M., Fedorov M.P., Nesterova N.V., Makarieva O.M. Suprapermafrost subaerial taliks, Central Yakutia, Shestakovka river basin. Earth's Cryosphere, 2019, vol. 23, no. 1, pp. 35-44.

10. Permafrost-Landscape Map of the Yakutian ASSR. Scale 1 : 2500000. Mel'nikov P.I., Ed. Moscow: GUGK, 1991. 2 sheets. (In Russ.).

11. Mikhailov V.M. Variations and estimates of mean flood discharges in rivers of the north-eastern Russia. Vestn. SVNTS DVO RAN, 2014, no. 2, pp. 21-26. (In Russ.).

12. Molchanov A.A. Gidrologicheskaya rol' lesa [Hydrological Role of Forest]. Moscow: Akad. Nauk SSSR, 1960. 487 p.

13. Nesterova N.V., Makar'eva O.M., Vinogradova T.A., Lebedeva L.S. Modelling runoff formation processes at the BAM zone based on the data of the "Mogot" research site. Vodn. Khozyaistvo Rossii, 2018, no. 1, pp. 18-36. (In Russ.).

14. Onuchin A.A. The reasons for conceptual contradictions in evaluating hydrological role of boreal forests. Sib. Lesnoi Zh., 2015, no. 2, pp. 41-54. (In Russ.).

15. Pozdnyakov L.K. Merzlotnoe lesovedenie [Permafrost Forest Science]. Novosibirsk: Nauka Publ., 1986. 192 p.

16. Pugachev A.A. Top soil in the territory of the Kolyma water balance station. In Faktory formirovaniya obshchego stoka gornykh rek $v$ Subarktike [Factors of Formation of the Total Flow of Mountain Rivers in the Subarctic]. Magadan: SVK NII DVO RAN, 2002, pp. 141166. (In Russ.).

17. Resursy poverkhnostnykh vod SSSR [Resources of Surface Waters of the USSR]. Vol. 17: Leno-Indigirskii raion [Lena-Indigirka Region]. Leningrad: Gidrometeoizdat Publ., 1967. 649 p.

18. Teplovodoobmen merzlotnykh landshaftov Vostochnoi Sibiri i ego faktory [Exchange of Heat and Water of Permafrost Landscapes of Eastern Siberia and Its Factors]. Georgiadi A.G., Zolotokrylin A.N., Eds. M., Tver': Triada Publ., 2007. 576 p.

19. Yasinskii S.V. Water balance of natural zones of the Volga's basin in phases of long-term period, different in streamflow rate. Izv. Akad. Nauk, Ser. Geogr., 2013, no. 6, pp. 86-101. (In Russ.).

20. Dolman A.J., Maximov T.C., Moors E.J., Maximov A.P. Elbers J.A., Kononov A.V., Waterloo M.J., vanderMolen, M.K. Net ecosystem exchange of carbon dioxide and water of far eastern Siberian Larch (Larix cajanderii) on permafrost. Biogeosciences, 2004, no. 1, pp. 133-146.

21. Fedorov A.N., Gavriliev P.P., Konstantinov P.Y., Hiyama T., Iijima Y. Iwahana G. Estimating the water balance of a thermokarst lake in the middle of the Lena River basin, eastern Siberia. Ecohydrology, 2014, vol. 7, no. 2, pp. 188-196. doi 10.1002/eco.1378

22. Hamada S., Ohta T., Hiyama T., Kuwada T., Takahashi A., Maximov T.C. Hydrometeorological behaviour of pine and larch forests in eastern Siberia. Hydrol. Process., 2004, vol. 18 , no. 1 , pp. $23-29$.

23. Ohta T., Hiyama T., Tanaka H., Kuwada T., MaximovT.C., Ohata T., Fukushima Y. Seasonal variation in the energy and water exchanges above and below a larch forest in eastern Siberia. Hydrol. Process., 2001, vol. 15, no. 1, pp. 1459-1476. 